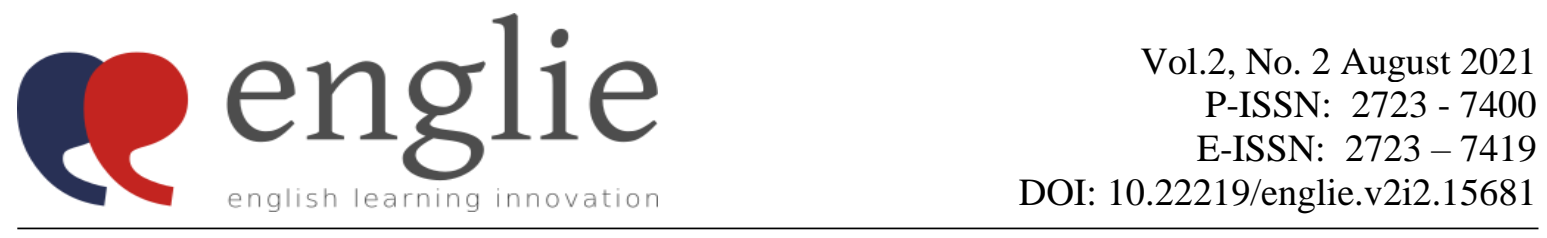

\title{
Improving Student Reading Comprehension through Question and Answer Relationships
}

\author{
Hanny Kusumawardani \\ English Language Education Department, Universitas Muhammadiyah Jakarta \\ Corresponding Author: hannykusumawardani@gmail.com \\ Dian Rosydiyanti \\ English Language Education Department, Universitas Muhammadiyah Jakarta \\ Nindy Astari Resta Utami \\ English Language Education Department, Universitas Muhammadiyah Jakarta
}

\begin{abstract}
Reading comprehension is the ability to process text, understand the purpose of the text and integrate with what the reader knows. The ability of individuals to understand texts is influenced by their abilities and ability to process information. The method that the writer use in this study is the question and answer relationships method in reading a narrative text. The application of the study is the teacher asks students to read a text about Malin Kundang and Sangkuriang. They were divided into six groups consist of five students each, and they had two section to make a questions and answer from the following topic. The research was conducted in classroom of $10^{\text {th }}$ grade at SMA Muhammadiyah 5 Jakarta. The hypothesis of this research is the question and answer relationships method is effective in improving students reading comprehension or not. And the result of the study is some of the students understand and get a high score using this questions and answer method (excellent: $60 \%$ students), and the students who understand and get a good score (good: 15\%), and students who understand but have to get an explaination first from the teacher (fair: 10\%), and last was the students who do not like English subject so they get poor score but, in the end, they get a remedial to improve their reading comprehension (poor: 5\%). This method was success to make student improve their reading aspects and would gladly use in the future too.
\end{abstract}

Keywords: narrative text; reading comprehension; question and answer relationships methods

Englie: English Learning Innovation, 2(2), 15-28 
Hanny Kusumawardani, Dian Rosydiyanti,

Nindy Astari Resta Utami
Social Function Improving Student Reading Comprehension through Question and Answer Relationships

\section{INTRODUCTION}

Starting point in learning English for most students in Indonesia start with young learners, and ironically their skills stage is in a basic stage. The stages for Indonesian students in learning English is starting from the young age learners until the university stage. From that, all the learners are learning English with different style according their levels of understanding. The government as the main holder of education in Indonesia still searching and adaptating the best learning method, strategy and approach to make the students fluent in mastering English and become like a native speaker (Mutiarani \& Rahman 2019).

Alderson (2000) mentions reading, through which readers can access worlds of ideas and feelings, as well as the knowledge of ages and visions of the future, is at once the most extensively researched and the most enigmatic of the so-called language skills. Reading skill is one form of mastery in English and the ability to read. Learning reading skills includes mastery of vocabulary will increase quickly, understanding the structure of sentences will form by itself, and grammar understanding will form by itself.

In learning English, four skills should be mastered by every student. There are listening, speaking, reading and writing. Reading become one of the skills that are not easy to learn because in learning reading, the students are not only required to understand the meaning of each word and have to comprehend the entire of reading text, but also expected to read the text in good pronunciation. Grabe \& Stoller (2011) state reading is the competence to interpretate the meaning and the information from written text correctly. Thus, reading becomes essential because the students can get current information and can enhance their knowledge by reading activity.

In the aspect of English, especially reading, students are expected to not only be able to pronounce words in English correctly, they must also understand the contents of the reading. According to Bazerman, Bawarshi \& Reiff (2013), critical reading in one's own and other's writing will help the reader to foster their metacognitive reflection, rhetorical awareness, and writing knowledge. As reading and writing are interconnected skills, they assume that advanced writers are likely to have extensive experience as a reader.

In fact, the activity of reading English texts has not become a habit in students' daily activities. The activity of reading English texts become learning reading material in formal 
lectures and some of the students find it boring and they are not too enthusiastic to choose reading material and understand the contents.

"Reading is always a meaningful activity with a goal that involves the reader's feelings, knowledge and experiences" (Mikeladze, 2014, p. 1). In the end, reading activities can unite intentions and interests of readers, so the process of transfer the meaning from mind to mind between the reader and writer can be intertwined to create meaningfulness in reading activities.

Snow (2012) states reading comprehension is a process to get a precise understanding of the author's message. In which to comprehend the text, the readers have to construct and collaborates their prior or background knowledge with the information in written text simultaneously. When the students want to learn reading comprehension, of course they need a type of reading text to read. Besides, in reading there are several types of reading text such as narrative text, report text, recount text, etc. In this study, the writer will use narrative text as a reading text to improve students reading comprehension.

"Question and answer method is teaching method to enrich student's creativity. The question and answer are a way to convey or present learning material from teacher that giving the question to students and the students have to answer it. And in other occasion, the students can ask a question to teacher about subjects that they don't understand, and the teacher can give an answer" (Partin, 2005, p11). Therefore, in its application, the teacher and students must be involved in the activity of asking and giving responses to the questions that exist. This question-and-answer method is considered quite effective in improving students learning outcomes. Then, there is one more opinion that says, that the question-and-answer method is one of the most effective and efficient teaching methods in building student creativity in the learning process.

The advantages of question-and-answer methods for students in tenth grade in senior high schools are:

1. Questions can attract and focus students' attention even when students are being noisy, sleepiness will come back refreshed and will disappear sleepiness.

2. This method can stimulate students to train and develop their thinking and memory. 
3. Developing the courage and skills of students in answering and expressing opinions.

4. Questions can reduce the process of forgetting.

5. Questions can lead to a desire to conduct an investigation.

"There is no doubt that reading speed and comprehension are closely linked. A very slow reader likes to read with poor understanding, if only because his memory is taxed: the beginning of paragraph — or even a sentence - may have been forgotten by the time he has struggled to the end of it" (Nuttal, 1988, p. 33). But it is not clear which is cause and effect: do people read quickly because they understand easily, or do they understand easily because of the speed with which they read.

Teaching and learning process without the proper method and media is simply a failure to deal with, as stated by Hadi (2019). From all of the main problems facing by the students, choosing the right method and media is important to improve students reading comprehension. That is the reason why in this research focuses on the use of proper method and media in teaching English, especially for those students who come with the transition period after the graduate from Junior High School (tenth grade in Senior High School).

\section{METHODS}

This study uses classroom research to know the progress of the students' reading comprehension with question-and-answer relationships. "In recent years action research has been solve the problem involve the curriculum development and in service education, particularly within the field of self-evaluation" (Arikunto, 2006, p. 57). The question-andanswer method can be done individually, in groups, or classically, between student and teacher, student and student, teacher to student.

Thus, the desired learning objectives can be achieved well by students. This questionand-answer method can also provide stimulation to be able to think critically and encourage students to make more effort to understand each question from teacher. With this method, it can enable the creation of activities of students' mental processes to see the connectedness available in learning materials. Therefore, the writer believes that the question and answer 
Hanny Kusumawardani, Dian Rosydiyanti,

Nindy Astari Resta Utami
Social Function Improving Student Reading Comprehension through Question and Answer Relationships

method is very good for collecting students' ideas based on what they get through books or any sources they read.

Therefore, in the application of the question-and-answer method in the learning process a teacher is required to prioritize the realization of the advantages of this questionand-answer method. The question-and-answer method can improve the reading comprehension of the students in narrative text. Which question about the type of text, what is the aim of the text, what the characteristics of the text, what used tenses in narrative text, what the general structure of the text, which the text concludes about orientation, event, and reorientation. Therefore, from the question the students can understand the content of the text. The complete answers of the questions were then constructed in a certain way to make a well-organized narrative text.

Brown (2004) states that there are some principal strategies for reading comprehension. They are:

1. Identify your purpose in reading a text.

2. Apply spelling rules and conventions for bottom-up decoding.

3. Use lexical analysis (prefixes, roots, suffixes, etc.) to determine meaning.

4. Guess at meaning (of words, idioms, etc.) when you aren't certain.

5. Skim the text for the gist and for main ideas.

6. Scan the text for specific information (names, dates, key words).

Wenden (1987 cited in Alderson 2000) notes that the strategies have been labelled differently in the literature and goes on to list the following: techniques, tactics, potentially conscious plans, consciously employed operations, learning skills, basic skills, functional skills, cognitive abilities, language processing strategies and problem-solving procedures.

However, reading comprehension is itself an activity to build understanding of the meaning of a text which can then be translated by you and though your own language. In the comprehending of the text, there are three kind of techniques that will help the reader become a better reader, they are:

\section{Skimming}


Hanny Kusumawardani, Dian Rosydiyanti,

Nindy Astari Resta Utami
Social Function Improving Student Reading Comprehension through Question and Answer Relationships

"Skimming is a prediction strategy used to give a reader a sense of the topic and purpose of a text, the organization of the text, the perspective or point of view the writer" (Brown, 200, p. 213). Skimming is a reading technique with high speed to look for things that are important or main idea of a reading.

\section{Scanning}

"Scanning is quickly reading to find the specific information. scanning is quickly searching for some particular piece of piece of information in a text" (Mikulecky \& Jeffries as quoted by Risdianto, 2012, p. 22).

\section{Intensive/Deep Reading}

Intensive reading is reading through every word of a text from beginning to end. McDonough \& Shaw (2012) state teachers should provide materials that stimulate interest for their students.

Skimming and scanning speed reading technique is often done by the reader. Both of these techniques are actually very functional, especially in day-to-day activities. Reading skill are arranged systematically to obtain efficient results separately various purposes, a case of the following:

a. To identify the topic of reading.

b. To find out the opinion of reading.

c. To determine the organization of writing.

d. To get the important part that we need a whole without reading.

In teaching reading skills, the writer use the question and answer method for tenth grade students of SMA Muhammadiyah 5 Jakarta. The participant are 30 students in one class. They have to make a group, consist of 5 students in every group, make a total of 6 groups. This research focus on reading comprehension and discussing the text, which is narrative text. The teacher is giving a topic of the text and the students have to make questions from the topic of the text, also have to answer the questions from the other group.

Narrative text can be a factual or imaginary story to entertain the reader (Lisandy \& Adijaya, 2019). It is called imaginary because the story is not necessary tells the truth but it could be just imagination or fictional story that made by someone or a group of people who 
have not proven the truth. The example of an imaginary story is like fairy tales, legends, romances, mysteries, fables, myths and adventure stories. Many different types of narrative; namely humor, fantasy, romance, historical fiction, crime, real life fiction, mystery, science fiction, diary novel, and adventure (Anderson \& Anderson, 2010).

In this research, there will be two sections. But before the first section and second section begin, the teacher gives two different texts for each group. The first section text is about "Malin Kundang". All the students have to understand the main ideas before they write or make a questions. And all of the group itself have to know the correct answer.

And the second section is similar to the first section, but the different is the other team who answering the questions will be the one who give the questions. The teacher is giving a different topic which is "Sangkuriang" to make questions to the other group. The students also have to understand the main ideas first, and then make questions to the other group.

\section{Section 1}

Topic: Malin Kundang

\begin{tabular}{ccl}
\hline No. & Question & Answer \\
\hline 1. & Group 1 & Group 2 \\
\hline 2. & Group 3 & Group 4 \\
\hline 3. & Group 5 & Group 6 \\
\hline
\end{tabular}

\section{Section 2}

Topic: Sangkuriang

\begin{tabular}{ccl}
\hline No. & Question & Answer \\
\hline 1. & Group 2 & Group 1 \\
\hline 2. & Group 4 & Group 3 \\
\hline 3. & Group 6 & Group 5 \\
\hline
\end{tabular}

Thus, these two sections are similar in implementing but with different topic to make a question and give an answer. The time in making a question from each group is at the same time, they also answering it at the same time. The teacher will give twenty minutes to make 
a question and answer in their paper works. After all of the students done answering the questions on their paper, the students have to explain in a brief and give a summary of the story. There will be a time when the teacher and students discussing the answer together. And in the end, the teacher will give the score to each group and give a conclusion about the topic, objection and suggestion to the students.

\section{FINDINGS AND DISCUSSION}

Based on the data analysis, there is an improvement of students reading comprehension. It is proven from the progress of reading achievement. The students can work in a group but they also can interact with the other group. By doing this method, students start from reading a text, understand the topic and main idea of the text, discussing with the group member, make questions based on the text, read actively and try to find the answer together.

\section{Section 1}

Topic: Malin Kundang

Group 1 have to give questions to Group 2. And Group 2 have to answer the question from Group 1.

Table 1.1

\begin{tabular}{|c|c|c|}
\hline No. & $\begin{array}{l}\text { Questions } \\
\text { (Group 1) }\end{array}$ & $\begin{array}{c}\text { Answer } \\
\text { (Group 2) }\end{array}$ \\
\hline 1. & $\begin{array}{l}\text { Why did Malin Kundang and his } \\
\text { mother has to live hard? }\end{array}$ & $\begin{array}{l}\text { Because his father had passed away } \\
\text { when he was a baby. }\end{array}$ \\
\hline 2. & $\begin{array}{l}\text { Give an example of Malin Kundang } \\
\text { was a healthy, diligent, and strong boy! }\end{array}$ & $\begin{array}{l}\text { He usually went to sea to catch fish. } \\
\text { After getting fish, he would bring it to } \\
\text { his mother, or sell the caught fish in the } \\
\text { town. }\end{array}$ \\
\hline 3. & $\begin{array}{l}\text { What happened many years after Malin } \\
\text { Kundang join the sail? }\end{array}$ & $\begin{array}{l}\text { He became wealthy after join the sail } \\
\text { many years. }\end{array}$ \\
\hline
\end{tabular}


Hanny Kusumawardani, Dian Rosydiyanti,

Nindy Astari Resta Utami
Social Function Improving Student Reading Comprehension through Question and Answer Relationships

The next group is from Group 3 and Group 4. The Group 3 have to give different questions. Because if they give the same questions that already mention from previous group, the answer will be the same too.

Table 1.2

Question

No.

(Group 3)
Answer

(Group 4)

1. How did the local people react when The local people recognaizes that it was they saw Malin Kundang landing on Malin Kundang, a boy from the area. The the coast? news that Malin has become rich ran fast in the town.

2. What did Malin Kundang's mother do Malin kandang's mother ran to the beach when she heard that Malin Kundang to meet the new rich merchant when she landead on the coast? heard that Malin Kundang landead on the coast.

3. What made Malin Kundang mother sad Malin Kundang mother was sad and and angry? angry because Malin denied that she was her mother and he yelled at her.

The last group is from Group 5 and Group 6. It will be the biggest challenge for Group 5 to give questions, because six questions already mention from the other previous groups.

Table 1.3

\begin{tabular}{lll}
\hline No. & \multicolumn{1}{c}{$\begin{array}{c}\text { Question } \\
\text { (Group 5) }\end{array}$} & \multicolumn{1}{c}{$\begin{array}{c}\text { Answer } \\
\text { (Group 6) }\end{array}$} \\
\hline 1. & What did she do when Malin Kundang & She cursed Malin Kundang that he would \\
& denied that she was his mother? & turn into a stone if he didin't appologize \\
& to her.
\end{tabular}


Hanny Kusumawardani, Dian Rosydiyanti,

Nindy Astari Resta Utami
Social Function Improving Student Reading Comprehension through Question and Answer Relationships

2. What is the moral of story? The moral of story is that we have to respect our parents, especially our mother.

3. Where the story come from? The story come from West Sumatera.

\section{Section 2}

Topic: Sangkuriang

The students already read the text about Sangkuriang and teacher will give a time for them to make questions to give it to the other group.

Table 2.1

\begin{tabular}{lcc}
\hline No. & Questions & Answer \\
& $($ Group 2) & (Group 1)
\end{tabular}

1. Why Sangkuriang kill Tumang? Because Tumang can't hunt the deer.

2. What happened with Sangkuriang after She banged Sangkuriang's head with a Dayang Sumbi knows he was a spoon and expelled Sangkuriang from murderer of Tumang? home.

3. What requirement that Dayang Sumbi Sangkuriang must built a huge river and a set to cancelled the wedding? boat for her before the dawn.

The next group is from Group 4 giving question to Group 3. The Group 4 will make different questions to Group 4.

Table 2.2

\begin{tabular}{|c|c|c|}
\hline No. & $\begin{array}{l}\text { Questions } \\
\text { (Group 3) }\end{array}$ & $\begin{array}{l}\text { Answer } \\
\text { (Group 2) }\end{array}$ \\
\hline 1. & $\begin{array}{l}\text { Why Dayang Sumbi won't marry } \\
\text { Sangkuriang? }\end{array}$ & $\begin{array}{l}\text { Because she is know that Sangkuriang is } \\
\text { her son with Tumang. }\end{array}$ \\
\hline & $\begin{array}{l}\text { Is Sangkuriang can fulfill the } \\
\text { requirement? }\end{array}$ & $\begin{array}{l}\text { No, because the dawn has come before he } \\
\text { can finished it. }\end{array}$ \\
\hline
\end{tabular}


3. What happened to Sangkuriang after He disappointed and break down the river knowing that Dayang Sumbi are cheat he has made, and kicked the boat upside on him? down.

And then, the last group is Group 6 and Group 5. After this question and answers, the students have to give conclusions from each group. They have to choose one of their friends to explain in a short time about the story.

Table 2.3

\begin{tabular}{|c|c|c|}
\hline No. & $\begin{array}{l}\text { Questions } \\
\text { (Group 6) }\end{array}$ & $\begin{array}{c}\text { Answer } \\
\text { (Group 5) }\end{array}$ \\
\hline 1. & What you can learn from the story? & $\begin{array}{l}\text { We have to pry into person before we can } \\
\text { trust him/her. }\end{array}$ \\
\hline 2. & Where the folklore come from? & The story is from West Java. \\
\hline 3. & $\begin{array}{l}\text { The boat which Sangkuriang made are } \\
\text { changed to mountain. What its called? }\end{array}$ & Its called Tangkuban Prahu Mountain. \\
\hline
\end{tabular}

There was a difference significant of students' reading comprehension before and after being taught using fairy tale or folklore. Some of the groups are easy to make a question and for the others are still asking for more time to.

And some of the groups are able to answer the questions without looking at the text, so it means they are already known and understand the story.

This research was focused on reading comprehension aspects using question and answers relationships in reading text. Then, from the calculation, it can be seen that the most increase was in finding main idea aspect and the lowest increase was inference. From the level of comprehension result, it concludes that the highest increase was literal comprehension and the lowest increase was critical comprehension. 
Hanny Kusumawardani, Dian Rosydiyanti,

Nindy Astari Resta Utami
Social Function Improving Student Reading Comprehension through Question and Answer Relationships

Table 3.1

The classification of the score:

\begin{tabular}{ccc}
\hline No & Classification & Score \\
\hline 1 & Excellent & $75-100$ \\
\hline 2 & Good & $50-74$ \\
\hline 3 & Fair & $25-49$ \\
\hline 4 & Poor & $0-24$ \\
\hline
\end{tabular}

\section{Graphic 3.1}

The Result of Research

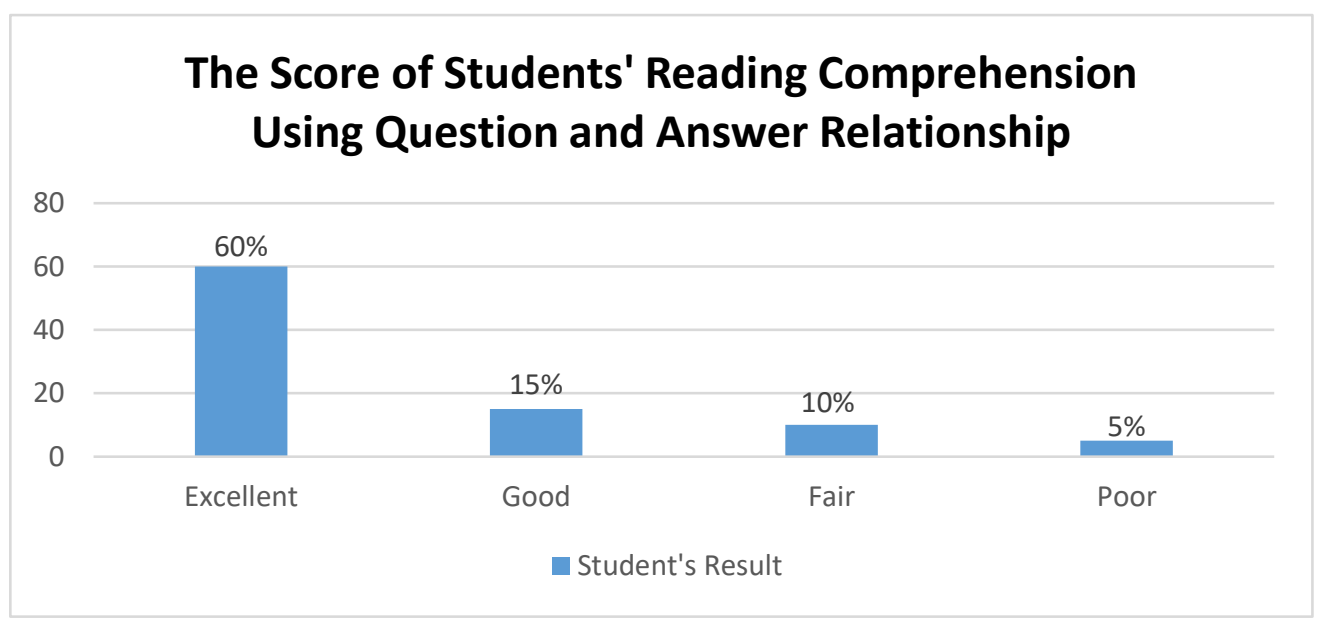

\section{CONCLUSION}

The main research goals of the study are improving students reading comprehension skills with question-and-answer method. The implementation is doing in the classroom. For students, this question-and-answer method can make students become more diligent in reading and understanding every reading and questions given by the teacher, and for teachers, asked to provide more material and methods that can make students become more active and effective in each reading subjects. Overall, it can be interpreted that the question-and-answer 
method in this reading lesson is considered quite effective in improving results student learning in class.

In this part, we would like to states some suggestions related with this study which might give contribution for the teacher to conduct better methods and also some beneficial suggestion for the reader. We suggest for the reader also teacher that might use fairy tales or folklore for teaching reading for students that the story must be familiar to the students, because unfamiliar fairy tales' story will unable to help students to connect their background of knowledge while they are reading. Besides, teacher also should pay attention on students' ability for its consideration when choose the text that teacher going to use. The fairy tales' story that uses by the teacher for teaching material must be equal with the students' knowledge.

\section{REFERENCES}

Alderson, J.C. (2000). Assessing reading. Cambridge University Press.

Anderson, M., \& Anderson, K. (2010). Text types in English 3. Macmillan Education Australia.

Arikunto, S. 2006. Metode Penelitian Kualitatif. Bumi Aksara.

Bazerman, C, Bawarshi, A., \& Reiff, M. J. (2013). Series Editors' Preface. In A. S. Horning \& E. W. Kraemer (Eds.), Reconnecting Reading and Writing (p. 325). Anderson SC: Parlor Press.

Brown, H. D. (2004). Language assessment: principles and classroom Practices. New York: Pearson Education, Inc.

Grabe, W., \& Stoller, F. L. (2011). Teaching and researching reading. Routledge.

Hadi, M. S. (2019). The use of song in teaching English for junior high school student. English Language in Focus (ELIF), 1(2), 107-112.

Lisandy, N., \& Adijaya, N. (2019). The effectiveness of using collaborative strategic reading (csr) on students' reading comprehension of narrative text. English Language in Focus (ELIF), 2(1), 53-58. 
McDonough, J., \& Shaw, C. (2012). Materials and methods in ELT: A Teacher's guide. Wiley: Blackwell Pub.

Mikeladze, T. (2014). Extensive reading (N. Dogonadze, Ed.). Retrieved from https://www.researchgate.net/publication/280878633_Extensive_Reading.

Mutiarani, \& Rahman, I. A. (2019). Theme based instruction model in teaching extensive reading. English Language in Focus (ELIF), 2(1), 43-52.

Nuttal, C. 1988. Teaching reading skills in a foreign language. Oxford: Heinemann International Publishing.

Partin, Roland L. 2005. Classroom teacher's survival guide (second edition). A Wiley Imprint.

Risdianto, F. 2012. Effective and efficient reading. solo: Rustam Publisher.

Smarapradhipa, G. 2005. Bertutur dalam tulisan. Raya Kultura.

Wahyu, W. 2001. Management Bahasa. Jakarta: Gramedia.

Snow, C. E. (2012). Reading for understanding: toward an r\&d program in reading comprehension. RAND Corporation.

Wenden, A. L. (1987). Metacognition: An expanded view on the cognitive abilities of L2 learners. Language Learning, 37 (4), 573-594. 